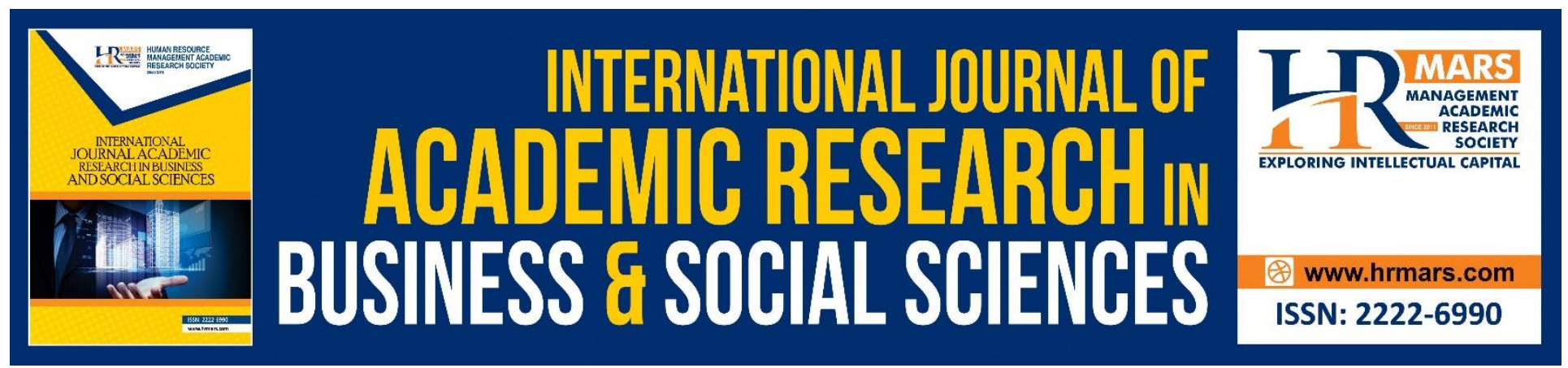

\title{
Qualitative Investigation of Sensitive Topics in Tax Compliance Study in Malaysia
}

Raihana Mohdali, Wan Normeza Wan Zakaria, Nor Adura Mohd Ali, Zarina Abdul Salam

To Link this Article: http://dx.doi.org/10.6007/IJARBSS/v9-i3/5798

DOI: $10.6007 /$ IJARBSS/v9-i3/5798

Received: 15 February 2019, Revised: 27 Februay 2019, Accepted: 01 March 2019

Published Online: 29 March 2019

In-Text Citation: (Mohdali, Zakaria, Ali, \& Salam, 2019)

To Cite this Article: Mohdali, R., Zakaria, W. N. W., Ali, N. A. M., \& Salam, Z. A. (2019). Qualitative Investigation of Sensitive Topics in Tax Compliance Study in Malaysia. International Journal Academic Research Business and Social Sciences, 9(3), 1307- 1319

\section{Copyright: (C) 2019 The Author(s)}

Published by Human Resource Management Academic Research Society (www.hrmars.com)

This article is published under the Creative Commons Attribution (CC BY 4.0) license. Anyone may reproduce, distribute, translate and create derivative works of this article (for both commercial and non-commercial purposes), subject to full attribution to the original publication and authors. The full terms of this license may be seen

at: http://creativecommons.org/licences/by/4.0/legalcode

$$
\text { Vol. 9, No. 3, 2019, Pg. } 1307 \text { - } 1319
$$

Full Terms \& Conditions of access and use can be found at http://hrmars.com/index.php/pages/detail/publication-ethics 


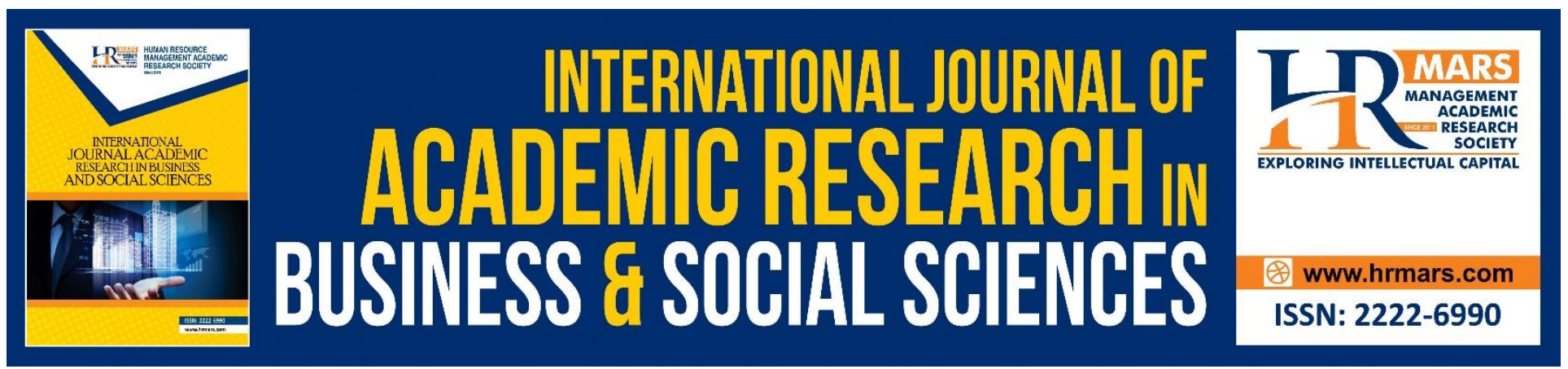

\title{
Qualitative Investigation of Sensitive Topics in Tax Compliance Study in Malaysia
}

\author{
Raihana Mohdali ${ }^{1}$, Wan Normeza Wan Zakaria ${ }^{1}$, Nor Adura Mohd \\ Ali $^{2}$, Zarina Abdul Salam ${ }^{3}$ \\ ${ }^{1}$ Razak Faculty of Technology and Informatics, Universiti Teknologi Malaysia, Kuala Lumpur, \\ Malaysia \\ ${ }^{2}$ Centre for Languages and Pre-University Academic Development, International Islamic University \\ Malaysia, Selangor \\ ${ }^{3}$ Azman Hashim International Business School, Universiti Teknologi Malaysia, Kuala Lumpur, \\ Malaysia
}

\begin{abstract}
Most researchers would probably agree on subject matters that possess sensitive elements such as income, sex, religion and politics. These topics are believed to be relatively intrusive and inappropriate to some. The same goes to issues related to tax compliance and other pressing matters surrounding it. Thus, the purpose of this research is to probe areas related to tax compliance study that can be considered as sensitive. Depth interview was employed for this qualitative study to collect data. The interviews were conducted with 14 taxpayers from various age groups and social backgrounds. The findings were analysed based on the verbal responses recorded and transcribed from all participants in verbatim. Issues related to government and religions have resulted in intensed reactions by the respondents more so than other topics. This is evident in the verbal responses, physical reactions and emotions portrayed by the participants. There are two main constraints in the study which are the different race and religious faith between the researcher and participants and the small number of the subjects involved in this study. Topics related to government issues are seen to top the list in causing the most extreme reaction in respondents followed by questions on the role of religious values. Questions on other areas do not trigger much stir.
\end{abstract}

\section{Introduction}

Data collection process appears to be a challenging task for almost all researchers in ensuring the reliability of data and the validity of the findings. This is probably more challenging for researchers involved in studies that address some of society's most pressing social issues commonly associated with sensitive topics. There are some identified topics or areas of research in the prior studies that are highly likely to be classified by definition as sensitive such as the issues that involve sex, religiosity or any powerful group such as government (Lee, 1993). Lee (1993) also emphasizes that, despite the long list of topics stated as sensitive in previous studies, any topic is possible to be regarded as 
sensitive depending on its context and environment, not on the individual topic. Similarly, based on the review of the sociological research literature, van Meter (2000) also concludes that a topic will be considered as sensitive when the majority of society defines it as sensitive.

Some of the researchers in tax compliance study such as Lozza et al. (2013); Darwish (2016) also regarded tax compliance as a sensitive topic due to its nature that involves people to reveal their true compliance intentions and attitudes. Furthermore, adding another sensitive topic such as religiosity and perceptions towards government in understanding taxpayers' compliance attitudes might further cause the sensitivity level to be stirred, hence concealing their actual compliance intentions and attitudes. However, proper strategies and techniques during interviews are suggested to be considered in reducing sensitivity in research and encouraging participants to provide only favorable responses (Elam and Fenton, 2003). Similarly, in tax compliance or tax evasion study, an appropriate technique employed during data collection such as indirect technique is expected to minimize the social desirability problem and consequently more likely to encourage taxpayers to share their true views (Kirchler and Wahl, 2010).

Therefore, this paper examines the actual topic that can be highly regarded as sensitive topic in tax compliance study in a multi-religious and multi-cultural country namely Malaysia. The remainder of the paper is organized as follows. The next section briefly reviews the topics that can be regarded as sensitive and techniques or strategies recommended during interviews for sensitive topics. Then, it is followed by the presentation of method employed in this study namely face-to-face interviews. Next, the findings and overall discussions are presented. Several limitations of the study are acknowledged and the final section concludes the paper.

\section{Sensitive Topics}

There are mixed views about the definition of sensitive topics. Lee $(1993$, p. 4) defines sensitive research as a study on a specific topic that "potentially poses a substantial threat to those who are or who have been involved with it". Dempsey et al. (2016) argue that most topics have the capacity to be sensitive if they evoke an emotional response. Tourangeau (2011) state that topic is sensitive because it involves intrusiveness, risk and social desirability. Whereas Wellings et al. (2000) classify research as sensitive if it requires disclosure of behaviors or attitudes which would normally be kept private and personal, which might result in offence or lead to social censure or disapproval, and/or which might cause the respondent to express with angst.

Tax compliance is one topic that fits the definition of sensitive topic as defined above especially when taxpayers intentionally do not fully fulfill their tax obligation. Intentional tax non-compliance attitude occurs when taxpayers purposely find ways to reduce the amount of tax paid. The attempts to reduce tax liability are done legally or illegally. The former is known as tax avoidance for example exploiting tax-loopholes. The latter indicates illegal means such as stating artificial transaction or underreporting income to reduce taxation, which is also known as tax evasion (Kirchler et al., 2003). Another sensitive topic is a topic related to religiosity. The term religiosity is often defined as an individual's conviction, devotion, and veneration towards divinity. Delener (1990) defined religiosity as the degree to which individuals are committed to a specific religious group. In a multi-religious and multi-cultural society like Malaysia, religious expression has always been monitored by the government in order to protect the racial harmony. This protection is clearly written in the constitution and has been in implementation to safeguard the country whenever issues on religions surface (Sani and Hamed, 2011). 
INTERNATIONAL JOURNAL OF ACADEMIC RESEARCH IN BUSINESS AND SOCIAL SCIENCES

Vol. 9, No. 3, March, 2019, E-ISSN: 2222-6990 @ 2019 HRMARS

Similar to religiosity, people are also very careful when talking or giving opinion about any issue related to government. Criticizing and showing disagreement towards government's actions is commonly be interpreted as inclination towards oppositions. Thus, many people may be under reporting or may decline to give their opinion about the ruling government in order not to reveal their stands. Tsai (2010) in his research on issues of political sensitivity in rural China found that topics such as local governmental performance and public goods provision are sensitive topics to government officials.

\section{Interview Issues in Sensitive Topics}

An interview is a conversation between researcher and research participants focusing on questions related to research topics (Merriam, 2009). In collecting data on sensitive issues, individual face-toface in-depth interview is commonly employed (Timraz et al., 2017; Ryan and Dundon 2008; DicksonSwift et al., 2007). In the face-to-face mode, non-verbal language and cues can be very rich, including dress, body language and mannerisms (Oltmann, 2016). Face-to-face approach also offers more possibilities to explore and uncover the feelings, emotions and also attitudes of participants (Crawford, 1997).

In-depth semi-structured interview is strongly suggested to be used for investigating sensitive topics (Elam and Fenton, 2003). Questions in a semi-structured interview are more flexibly worded or can be a combination of more and less structured ones (Merriam, 2009). The order of the questions and the exact wording are not determined ahead of time. This format gives the opportunity for the interviewer to explore particular themes or responses further.

Before going to the field to conduct an in-depth face-to-face interview on sensitive topics, there are a few elements that must be taken into considerations by researchers. The first practical considerations for any researcher are seeking permission and gaining access from the institution where they want to conduct the interview or/and from individual research participants (Walls, 2010). Jepson et al. (2015) suggested researchers to send interview schedule to potential respondents and explain the real issue that needed to be discussed with respondents from the beginning of the interview so that they could make a more informed decision about what the interview would cover. Another important element that must be done before an interview session is to guarantee anonymity. Anonymity refers to conditions in which participants' personal information and identities are kept secret (Saunders et al., 2015). However, it is argued that true anonymity is difficult to achieve because in a qualitative study, the researcher knows the identity of the participants and has to meet them personally (Scott, 2005). Therefore, the definition of anonymity in a qualitative study only applicable to people other than the researcher of that particular study (Saunders et al., 2015).

Researchers can build rapport with participants by engaging in a small talk using every day conversational style before beginning the interview (Gall et al., 2003). Good rapport helps both parties reconcile to the research agenda and uncovered much deeper extrapolations of lived experiences from the participants. Good rapport also leads to depth and quality of information and experiences revealed by participants (Elmir et al., 2011).

It is also important to allow participants adequate time to respond fully. In some cases, respondents were also being offered the option of omitting certain questions should they find the questions inappropriate to be responded during the interview. Data gathered through interviews must be recorded. Researchers can use field notes only, or a recording device, or both to record the data (Tessier, 2012). Field notes help researchers document what they observe, while recording device can ensure that everything said is preserved for analysis (Merriam, 2009). To end an interview 
INTERNATIONAL JOURNAL OF ACADEMIC RESEARCH IN BUSINESS AND SOCIAL SCIENCES

Vol. 9, No. 3, March, 2019, E-ISSN: 2222-6990 @ 2019 HRMARS

session, researchers can give a closing statement summarizing some of the important points and allowing an opportunity for participants to clarify information or add additional pertinent data.

\section{Research Method}

Data collection process is the most crucial part in any study. One of the most important issues is to ensure the reliability of data so that the interpretation of data is reflecting the true opinion of the participants particularly in a qualitative study. In-depth interview was used in this study and was considered as the best method to understand the perceptions of people on certain situation in assembling reality (Punch, 2005). In this study, the participants were sharing their opinions about the role of religious values, perceptions towards government and the impact of these elements on tax compliance attitudes. Since almost all of the topics involved in this study were regarded as highly sensitive in prior studies (e.g. Lee, 2003; Lozza et al., 2013), semi-structured in-depth interview was adopted as the interviewing format for this study. This is because it is considered as one of the most appropriate methods for a study that involves sensitive issues (Elam and Fenton, 2003). Semistructured in-depth interview is most widely adopted by researchers in qualitative study by having a set of pre-determined open-ended questions and other questions that might arise during the interviews (DiCicco-Bloom and Crabtree, 2006). This interviewing format has its flexibility in giving control to the interviewer in obtaining the information needed for the study and at the same time allows some space for interviewee/s to expand current issues or even discuss any arising issues (Hitchcock and Hughes, 1989).

The interview instrument was developed as a guideline which included a list of topics that needed to be explored during the interview. However, to minimize the issue of sensitivity during the interviews, the indirect questions were constructed so that the participants were more willing to share their opinions honestly and critically without any direct association with them (Nuno and John, 2015). The questions were not posed directly to gauge the participants' own views on the specific issues in this study but rather the way overall Malaysians were viewed by the participants regarding their compliance attitudes. The questions given to the participants were rather general in linking their views between religiosity, perceptions towards government and taxpayers' compliance attitudes.

The participants were contacted before the interviews and brief information regarding the topic coverage, duration of interview and anonymity assurance was given to the participants via email. During the interviews, participants were aware of what was expected from them based on the information sheet provided and they were also aware that they have the rights to withdraw from the interviews at any time without providing any reason. These were done to minimize distress and discomfort of the participants because an interview is normally considered as a sharing secrets session (Orb et al., 2000). In addition, the researcher had also tried to engage the participants in a small social conversation before shifting gradually to the actual conversation in order to create friendly environment for the interviews.

The in-depth interviews were conducted with 14 participants. Since one of the topics of this study was to explore the role of religiosity on tax compliance attitudes, the participants were selected based on their ethnicity to represent the four main religions in Malaysia namely Islam, Christianity, Buddhism and Hinduism because ethnicity was commonly associated with religion in Malaysia (Lee, 2000). The participants were also required to have a minimum of three years of experience in paying tax. This was to ensure the participants had sufficient experience in sharing their views about the research topic. 
The interviews were conducted either in English or Malay, depending on their preference to ensure they were comfortable in sharing their views openly with the researcher. The interviews were tape recorded with the consent of the participants to ensure all responses were captured for the transcription process. This process is expected to increase the validity of data gathering rather than depending on the note taking only (Fielding and Thomas, 2008). The information from the interviews was transcribed based on the recorded interviews. In this study, verbatim quotations were employed to reflect the real feelings, thoughts, experiences and basic perceptions of the participants (Neale et al., 2005). Therefore, the actual quotations were recorded even though some of the responses were grammatically incorrect.

The researcher also tried to be cautious when interviewing the participants who adhered to the same or different religion with the researcher who is a Muslim. Furthermore, since this study involved participants who came from a background of a number of different religions, the researcher had put her reasonable effort to be as cautioned as possible in asking questions to the participants and responding appropriately during the interview.

\section{Findings}

The interviews were conducted successfully with 14 participants from different backgrounds. There were seven males and seven females representing all age groups from the 20 s to 70 s with the largest group of participants in their 30s. The participants represented three major ethnic groups, namely Malay and other indigenous groups, Chinese and Indian. The participants were also representing major religions in Malaysia namely Islam, Christianity, Buddhism and Hindu.

Overall, the majority of the participants have given their full cooperation in sharing their views and opinion regarding the issues discussed in this study. Almost all of the participants appeared to be more open and truthful in discussing tax compliance issue even though tax compliance is highly regarded as one of the sensitive topics in previous studies (e.g. Lozza et al., 2013). All participants were not hesitated to express their opinions openly regarding the high tendency of taxpayers to avoid or pay lesser tax than they were supposed to pay particularly for business taxpayers. One of the participants, P6 had also willingly shared his personal experience with his family members regarding tax non-compliance issue. The selected responses for tax compliance issue are presented in Table 1.

\section{Table 1}

Selected responses to tax compliance question

Question : How strongly do you think Malaysians are complying with tax laws?
Responses : "I think in general, people would rather not to pay tax. As a human, we do
not want to pay tax because they are also certain perception or the worry of
the money does not go to it is supposed to be going." (P2, Muslim, General
Manager)
"Not really. Generally, people will try to evade. To pay less than they are
supposed to pay. They have their reasons also why they have to evade." (P5,
Christian, Self-employed)
"The wage earners have no option because documents are sent directly to
the IRBM. Only business people can take advantage. In fact, my older brother
in law, many years ago, he was earning five times that his wife was earning


but he only paid one-third tax she paid. This is not only in Malaysia, but uniformly around the world." (P6, Hindu, Consultant)

However, despite all the reasonable efforts that had been done by the researcher to ensure the participants were comfortable during the interviews, the researcher still faced difficult situation to convince some of the participants to share their views particularly on specific topics namely issues that involved religion and perception towards government. Upon responding to one of the religiosity questions, one participant (P10) clearly tried to avoid giving a direct answer but instead, emphasized on the requirement to be compliant regardless of the situation. Nevertheless, P4 and P11 who also adhered to the same faith with P10, were willing to indicate their stance generally regarding this issue. The responses to the question are shown in Table 2.

\section{Table 2}

Selected responses to religiosity question

\begin{tabular}{ll}
\hline Question & How do you think religious values can encourage or motivate people to \\
Responses : "Actually, if you asked me, I never bother much about this. I have to comply. \\
Whatever it is, I still need to comply. I can't go against government, right?" \\
(P10, Buddhist, Executive Officer) \\
"Actually, if you ask me from a Buddhist point of view, not much! People are \\
giving because of social cause. Even as a Buddhist, we give." (P4, Buddhist, \\
Senior Manager) \\
"I don't think religion told us whether to pay or not to pay. It is just that they \\
told us to be a good person." (P11, Buddhist, Executive Officer)
\end{tabular}

Similar response pattern was illustrated when the issue of religiosity was still being discussed, P10 seemed to be uncomfortable to continue with this issue and she tended to provide very brief and short answers, probably to indicate her true view of this topic without elaborating them. The interview with P10 only lasted for less than 15 minutes as compared to other participants who took a minimum of 30 minutes in average for each session. Even though all participants were already informed before the interview that there were no right or wrong answers and they might express opinions based on their perspectives, P10 still appeared to be reluctant to further discuss the religiosity topic. The followings are the examples of the questions that relate to religiosity posed to P10 and her responses are presented in Table 3.

\section{Table 3}

Responses to religiosity questions

\begin{tabular}{ll}
\hline Question : & $\begin{array}{l}\text { There are two religious commitments namely intrapersonal (spiritual) and } \\
\text { interpersonal (social) religiosity. Based on these, which do you think may } \\
\text { strongly influence people to comply with tax laws and why? }\end{array}$ \\
Response : "No influence." (P10, Buddhist, Executive Officer)
\end{tabular}


INTERNATIONAL JOURNAL OF ACADEMIC RESEARCH IN BUSINESS AND SOCIAL SCIENCES

Vol. 9, No. 3, March, 2019, E-ISSN: 222 2-6990 @ 2019 HRMARS

\begin{tabular}{lll} 
Response & :Disagree." (P10, Buddhist, Executive Officer) \\
\hline Question $:$ & Honestly, do you really believe that people are complying because of their \\
& religious values? Why? \\
Response : & "No way." (P10, Buddhist, Executive Officer)
\end{tabular}

Opinions of the participants about the Malaysians' perceptions towards the Malaysian government (the previous government before 9th May 2018) were also gathered. In this study, many of the participants were rather hesitant to give their opinion at first. After they were being convinced that this study was only for educational and not for policy making purposes as strongly suggested by Tsai (2010), then only half of the participants were more confident to briefly express their opinion. The other two participants namely P10 and P14 were clearly unwilling to respond to this matter and P10 strictly classified this topic as sensitive. The remaining of the participants responded but very briefly. They only provided simple terms to indicate the level of trust in government such as 'low', 'shaky' and 'not really' without elaborating the actual meaning of their responses. The questions and selected responses on this issue are shown in Table 4.

Table 4

Selected responses to perception towards government question

Question : What is your opinion about the citizen's trust in Malaysian government?
Responses : "That one is a very sensitive issue! As long as we have a very peaceful
country, so I don't bother much. No fighting, no riots. This is enough for me.
I consider this is a peaceful country." (P10, Buddhist, Executive Officer)
"This is very subjective. It is hard for me to say." (P14, Muslim,
Government Servant Retiree)
"I think a bit shaky." (P1, Muslim, Lecturer)
"Trust? Not really." (P8, Christian, Executive Officer)
"I think quite low. Honestly!" (P11, Buddhist, Executive Officer)
"The trust is a bit... I would say in general, people are questioning the
government now." (P12, Hindu, Senior Lecturer)
"Seriously, very low." (P13, Muslim, Tutor)

\section{Discussions}

In a research that involves sensitive topics, findings from interviews help researchers to gain insights into people's feelings and thoughts which may provide valuable knowledge in understanding their 
attitudes on certain issues. In the current study that combined a number of sensitive topics namely tax compliance, religiosity and perception towards government, there was no guarantee in getting rich results. This was because reassuring participants to voice out opinions freely was quite challenging even though many interviewing strategies were adopted by the researcher to ensure rich data can be gathered for these sensitive topics. However, based on the findings of the current study, this particular situation seemed to be applicable only to certain topics namely religiosity and perceptions towards government and certain participants.

The possible explanation for the findings related to religiosity might be due to the multi-religious nation in this country. Generally, those adhering to the religion of the majority can be considered as having religious privilege in a particular area or country and this might affect the members of the minority in subtle ways such as having to experience prejudice in a certain scenario. This was probably reflected by the responses made by P10 when she was quite reserved and somewhat reluctant to share her views specifically in religiosity topics because she adhered to the faith of the minority in Malaysia. Another possible explanation probably because some of the participants' viewpoints on religiosity issues particularly the Buddhists contradicted with the majority of the participants who agreed that religiosity seemed to have somewhat positive impact on taxpayers' compliance attitudes. Their reluctance probably due to the difference of opinion with the majority who normally incline to provide 'yes' answers to positive religious statements (Allport and Ross, 1967).

Additionally, since their faith and the researcher's faith were different, this situation probably had created an uneasy environment for them to share their thoughts and feelings regarding this issue. This is in line with the finding in a study conducted by Rey (1997) that confronting people hailing from different faiths and practices may probably hinder the participant to further elaborate on his/her honest views regarding this issue particularly from his/her religion's perspective. Besides that, Sani and Hamed (2011) also highlight that one of the main issues in a Malaysian plural society is the restriction to express religious matters freely and hence probably contributes to such responses in this study. Furthermore, getting high quality data in a short time (in P10's case only 15 minutes) was quite impossible because the researcher and participants could hardly develop a good reciprocal relationship that was based on trust (Tsai, 2010).

The findings related to perception towards government probably reflect the actual definition of sensitive topic as defined by Lee (1993) that participants might feel they are at risk if they express their true views. Hence, their hesitation can be linked to the possible risk they might be facing when they openly criticized about the Malaysian government. This is because even though Malaysians have the right to practice freedom of speech as stated in Federal Constitution 1999, Part 2 Article 10 (1), the freedom of speech was clearly suspended using Article 149 (Muda, 1996). Article 149 gives power to the Parliament to pass laws to suspend a person's fundamental rights vested to him in Part 2 of the Constitution if the Parliament believes that the person is a threat to national security or public order. One of the effects of this article is that people who critique the government can be legally silenced. This was clearly emphasized by one of the participants that the Malaysian government restricted the freedom of speech by stating that:

"... they cannot talk openly. Why? Because if they talk openly, this will be sensitive. There is no freedom of speech too. If you talk too much, there will be certain laws that can put you behind bars." (P5, Christian, Selfemployed)

Even though the government's clear intention is more likely to maintain harmony in the society and country, this restriction somehow has threatened the people's confidence towards the government 
and respect for laws (Khairuldin et al., 2017). More importantly, for the purpose of research, the restriction in voicing out opinions openly towards the government has seemed to have somewhat a negative impact in getting true and fair views and limiting the richness of data during the interviews. Therefore, the topic that involved the perceptions towards government might be regarded as more sensitive as compared to religiosity topic in this study.

On the other hand, the participants appeared to be very much comfortable in sharing their views and thoughts in tax compliance issue even though the conversation was led to the possibility of discussing the negative attitudes of Malaysian taxpayers. They were willing to voice out their sincere opinions probably because their responses did not really reflect their own attitudes but rather the view of Malaysians as a whole. This was probably because of the indirect questions posed to the participants in the interviews and hence encouraged them to be more sincere and honest in responding to those questions. The use of indirect questions during data collection is strongly suggested by Nuno and John (2015); Kirchler and Wahl (2010) when dealing with sensitive topics. More importantly, when questions on sensitive topic posed are not considered as sensitive by the interviewee, the topic is less likely to be sensitive (Meter, 2000) and the willingness of the participants can be anticipated. However, despite the same strategies employed by the researcher for all topics in this study, the discussions of the religiosity and Malaysians' perceptions towards government issues still seemed to be sensitive to some of the participants.

The obvious limitation of this study was the different background of the researcher who conducted this study with a number of participants particularly in terms of religious faith. This probably contributes to awkward situations between the participant and researcher during the interview which might lead to the disinclination of sharing their true views. Another obvious limitation was the small number of the participants involved in this study which probably has limited the access to the richness of data even though the ideal sample size of a qualitative study was not clearly stated in prior studies (Marshall et al., 2013). The key direction for future research from the present study is to possibly match the background of the researcher and participants which might encourage openness in participants and reduce awkwardness simultaneously. Increasing the sample size might also help to furnish researchers with more data, hence enhancing a better understanding of any sensitive topic in the future.

\section{Conclusions}

All in all, it is clear from the findings that the majority of the participants have openly and truthfully shared their views and opinions regarding the issues discussed in this study even though tax compliance is almost always viewed to be a sensitive topic. Nevertheless, when questions covering certain areas on tax compliance were posed, some participants chose to display a different tone. Across the board, topics related to government issues are deemed to be more sensitive than other topics dealt with in the interview questions. Questions on perceptions towards government are found to be more delicate than questions on the role of religious values and tax compliance attitudes. However, the issues on religiosity inevitably stir perturbed and somewhat defensive responses too, though less serious in most participants. Despite the effort to create 'safe' and comfortable atmosphere, some participants still display unpleasant reactions. The indicative nature of the participants' responses are demonstrated through short and brief responses, reluctance, hesitation and delays, taking long pauses to respond, attempts to avoid giving direct answers which can be translated into the feelings of uneasiness, agitation and discomfort during the interview session. 
These salient reactions are rather typical when one is dealing with his or her feelings by matching the physical reactions with his or her emotions.

Essentially, the very nature of tax as a topic of interview and discussion can already easily evoke the feelings of intrusion, let alone interfusing it with other controversial topics like religions and politics. This further can result in strong abhorrence, extreme reactions and opinions if not carefully administered or worse, it can pose risk to the well-being of the researcher. Hence, from this research, it is suggested that more careful measures for precautions are to be taken into consideration to lessen the possibility of evasive responses and extreme opinions. This can be done through the careful wording of questions and perhaps a preparation of list of optional questions on the side, in cases of having uncooperative participants. Another suggestion is to select participants who are devoted to the same religion with the interviewer or having more interviewers from different religious background to match with the background of the respondents. This careful planning can ensure researcher's effort to obtain reliable data and worthwhile information as well as to convince participants to remain calm, collected and truthful during interviews. Challenges are, without a doubt, part and parcel of conducting research, but preparation and strategies are key to yield favourable results and in handling precarious situation. What appears trivial and inconspicuous in nature, may be sensitive to others and when things derail, data and information gathered may not really represent their true perceptions.

\section{References}

Allport, G. W. \& Ross, M. (1967). Personal religious orientation and prejudice. Journal of Personality and Social Psychology, 5(4), 432-443.

Crawford, I. M. (1997). Marketing Research and Information Systems (Marketing \& Agribusiness Texts). Rome: Food \& Agriculture Organization of the United Nation.

Darwish, S. (2016). The Understanding of Probability in the Iraqi Culture. International Journal of Mainstream Social Science: Vol. 5, Nos. 1-2, 11.

Delener, N. (1990). An examination of the religious influences as predictors of consumer innovativeness. Journal of Midwest Marketing, 5(3), 167-178.

Dempsey, L., Dowling, M., Larkin, P. \& Murphy, K. (2016). Sensitive interviewing in qualitative research. Research in Nursing \& Health, 39, 480-490.

DiCicco-Bloom, B. \& Crabtree, B. F. (2006). The qualitative research interview. Medical Education, 40, 314-321.

Dickson-Swift, V., James E. L. \& Kippen, S. (2007). Doing sensitive research: what challenges do qualitative researchers face? Qualitative Research, 7(3), 327-353.

Elam, G. \& Fenton, K. A. (2003). Researching sensitive issues and ethnicity: lessons from sexual health. Ethnicity and Health, 8(1), 15-27.

Elmir, R., Schmied, V., Jackson, D. \& Wilkes, L. (2011). Interviewing people about potentially sensitive topics. Nurse Researcher, 19(1), 12-16.

Fielding, N. \& Thomas, H. (2008). Qualitative interviewing. In N. Gilbert, (Ed.), Researching Social Life (pp. 245-265). London: Sage Publications.

Gall, M. D., Gall, J. P. \& Borg, W. R. (2003). Educational Research: An Introduction. Boston: Allyn and Bacon.

Hitchcock, G. \& Hughes, D. (1989). Research and the Teacher: A Qualitative Introduction to Schoolbased Research. London: Routledge. 
INTERNATIONAL JOURNAL OF ACADEMIC RESEARCH IN BUSINESS AND SOCIAL SCIENCES

Vol. 9, No. 3, March, 2019, E-ISSN: 2222-6990 @ 2019 HRMARS

Jepson, M., Abbott, D. \& Hastie, J. (2015). This is another personal question: Research interviews and discussing sensitive issues with men with life-limiting conditions. International Journal of Men's Health, 14(3), 273-286.

Khairuldin, W. M., Embong, A. H., Anas, W. N., Ismail, D., Ibrahim, I. \& Fauzi, N. (2017). Freedom of speech: a comparative study between Islam and Malaysian laws. International Journal of Academic Research in Business and Social Sciences, 7(2), 908-915.

Kirchler, E., Maciejovsky, B. \& Schneider, F., (2003). Everyday representations of tax avoidance, tax evasion, and tax flight: Do legal differences matter? Journal of Economic Psychology, 24(4), 535-553.

Kirchler, E., \& Wahl, I. (2010). Tax compliance inventory: Tax-I voluntary tax compliance, enforced tax compliance, tax avoidance, and tax evasion. Journal of Economic Psychology, 31(3), 331-346.

Lee, H. G. (2000). Ethic Relations in Peninsular Malaysia: The Cultural and Economics Dimensions. Singapore: Institute of Southeast Asian Studies.

Lee, R. M. (1993). Doing Research on Sensitive Topics. Newbury Park, CA: Sage Publications.

Lozza, E., Kastlunger, B., Tagliabue, S. \& Kirchler, E. (2013). The relationship between political ideology and attitudes toward tax compliance: The case of Italian taxpayers. Journal of Social and Political Psychology, 1(1), 51-73.

Marshall, B., Cardon, P., Poddar, A. \& Fontenot, R. (2013). Does sample size matter in qualitative research?: A review of qualitative interviews in IS research. Journal of Computer Information Systems, 54(1), 11-22.

Merriam, S. B., (2009). Qualitative Research: A Guide to Design and Implementation, San Francisco, CA: Jossey-Bass.

Muda, W. A. (1996). Keadilan sosial dan kebebasan bersuara rukun negara maju. In A. Bahari \& C. Muzaffar (Eds.), Keadilan Sosial, Kuala Lumpur: Institut Kajian Dasar (IKD).

Neale, J., Allen, D., \& Coombes, L. (2005). Qualitative research methods within the addictions. Addiction, 100(11), 1584-1593.

Nuno, A. \& St. John, F. A. (2015). How to ask sensitive questions in conservation: A review of specialized questioning techniques. Biological Conservation, 189, 5-15.

Oltmann, S. M. (2016). Qualitative Interviews: A Methodological Discussion of the Interviewer and Respondent Contexts. Forum: Qualitative Social Research, 17(2). Retrieved from http://www.qualitative-research.net/index.php/fqs/article/view/2551/3998.

Orb, A., Eisenhauer, L. \& Wynaden, D. (2000). Ethics in Qualitative Research. Journal of Nursing Scholarship, 33(1), 93-96.

Punch, K. F. (2005). Introduction to Social Research Quantitative and Qualitative Approaches. London: Sage Publications.

Rey, L. D. (1997). Religion as invisible culture: knowing about and knowing with. Journal of Family Social Work, 2(2), 135-143.

Ryan, P. \& Dundon, T. (2008). Case research interviews: Eliciting superior quality data. International Journal of Case Method Research \& Application, 4, 443-450.

Sani, M. A., \& Hamed, S. D. (2011). Freedom of religious expression in Malaysia. Journal of International Studies, 7, 33-49.

Saunders, B., Kitzinger, J. \& Kitzinger, C. (2015). Anonymising interview data: Challenges and compromise in practice. Qualitative Research, 15(5), 616-632.

Scott, C. (2005). Anonymity in applied communication research: Tensions between IRBs, researchers, And human subjects. Journal of Applied Communication Research, 33(3), 242-257. 
INTERNATIONAL JOURNAL OF ACADEMIC RESEARCH IN BUSINESS AND SOCIAL SCIENCES

Vol. 9, No. 3, March, 2019, E-ISSN: 222 2-6990 @ 2019 HRMARS

Tessier, S., (2012). From field notes, to transcripts, to tape recordings: evolution or combination? International Journal of Qualitative Methods, 11(4), 446-460.

Timraz, S. M., Alhasanat, D. I., Albdour, M. M., Lewin, L., Giurgescu, C. \& Kavanaugh, K., (2017). Challenges and strategies for conducting sensitive research with an Arab American population. Applied Nursing Research, 33, 1-4.

Tourangeau, R. (2011). Sensitive topics. In P. J. Lavrakas (Ed.), Encyclopaedia of Survey Research Methods, Thousand Oaks: Sage Publications.

Tsai, L. L. (2010). Quantitative research and issues of political sensitivity in rural China. In A. Carlson, M. E. Gallagher, K. Lieberthal \& M. Manion (Eds), Contemporary Chinese Politics: New Sources, Methods and Field Strategies (pp. 519-549). New York: Cambridge Univ. Press.

Van Meter, K. M. (2000). Sensitive topics - sensitive questions: Overview of the sociological research literatures. Bulletin de Methodologie Socilogique, 68(4), 59-78.

Wellings, K., Branigan, P. \& Mitchell, K. (2000). Discomfort, discord and discontinuity as data: Using focus groups to research sensitive topics. Culture, Health \& Sexuality, 2(3), 255-267. 